\title{
Results of a regional cord blood screening programme for detecting neonatal hypothyroidism
}

\author{
PAUL G. WALFISH, JODY GINSBERG, R. ARLEN ROSENBERG, AND \\ NEVILLE J. HOWARD \\ Mount Sinai Hospital, University of Toronto, and Hospital for Sick Children, Toronto, Canada
}

SUMMARY Our regional cord blood screening programme for detecting neonatal hypothyroidism using initial cord blood thyroxine (T4) determinations, with supplemental thyrotropin (TSH), and triiodothyronine resin uptake (T3U) measurements, gave an incidence of thyroid abnormalities of $1 / 3000$ births, with 1/5000 infants having severe primary hypothyroidism. No hypothyroid infant detected in the programme had been suspected clinically before the screening and, in retrospect, only a few babies had any signs of hypothyroidism. Supplemental TSH and T3U determinations were required on $8-12 \%$ of the population screened initially with a T4 test to avoid missing affected cases. With an initial T4 and supplementary TSH and T3U testing on cord blood serum, recalls to exclude primary hypothyroidism were reduced to $0.16 \%$ of the screened population. The incidence of abnormalities detected in this cord blood screening programme was comparable with that reported by others using neonatal dried blood screening methods, indicating that cord blood screening can be effective provided the appropriate recall criteria and transport conditions are used. Nevertheless, for several practical reasons, neonatal dried blood methods are recommended as the screening test of choice for surveying large populations over extensive geographical areas.

Neonatal hypothyroidism is a condition that may result in mental retardation. Retrospective studies show that treatment before age 3 months lessens the chance of this outcome (Raiti and Newns, 1971; Klein et al., 1972). As it is difficult to make an early clinical diagnosis, laboratory screening programmes have been implemented (Fisher et al., 1976). Cord blood serum TSH alone (Klein et al., 1974), or thyroxine combined with thyrotropin (TSH) (Walfish, 1976), have been used. Alternatively, dried blood spotted on filter paper discs after heel prick at age 3-5 days has been used to measure T4 alone (Dussault et al., 1976), TSH alone (Irie et al., 1975; Illig and Rodriguez deVera Roda, 1976; Larsen et al., 1976; Miyai et al., 1976; Foley et al., 1977), or initial T4 with supplementary TSH

Department of Medicine, Endocrine Division, Mount Sinai Hospital, and University of Toronto

P. G. WALFISH, associate professor

J. GINSBERG, research fellow, Medical Research Council of Canada

R. A. ROSENBERG, research assistant

Department of Pediatrics, Endocrine Division, University of

Toronto, and Hospital for Sick Children, Toronto

N. J. HOWARD, associate professor
(Scriver et al., 1977; Dussault et al., 1978). Neonatal heel prick capillary serum TSH has also been assessed as a screening test (Delange et al., 1977).

To detect neonatal hypothyroidism and lessen the burden of recall in a screening programme using T4 alone (Walfish, 1976), our programme used an initial cord blood serum T4, with selective supplemental TSH and triiodothyronine uptake assays (T3U) to obtain epidemiological data on this disorder in Toronto. The purpose of this report is to summarise the laboratory and clinical data for the 16 infants with confirmed thyroid dysfunction among the 50000 infants who were tested in this large-scale regional screening programme.

\section{Materials and methods}

Cord blood sera and venous samples from patients who were followed up were obtained in a regional screening programme to detect neonatal hypothyroidism. The programme was started in October 1973 at the Mount Sinai Hospital, Toronto, and this was extended to other Toronto Hospitals with approval of the University of Toronto Committee on Human Experimentation. 
Cord blood was obtained after delivery and ligation of the umbilical cord by withdrawing with a syringe 3 to $5 \mathrm{ml}$ venous blood from the placental side. This was stored and taken at $4^{\circ} \mathrm{C}$ to a central laboratory. After being separated by centrifugation, sera were stored at $-20^{\circ} \mathrm{C}$ until analysis. All assays were performed in duplicate. Using $25 \mu$ l serum samples, cord T4 was measured in all infants by a double antibody radioimmunoassay (RIA) technique (Chopra, 1972; Walfish et al., 1973). Each assay 'run', comprising 200-700 samples, was analysed by a histogram and those infants with low T4 values up to either the 8th or 12th centile, depending on the distribution of values, had supplemental duplicate $100 \mu l$ serum TSH determinations, using a double antibody RIA (Patel et al., 1971) and duplicate 100 $\mu l$ serum T3 uptakes with silica talc resin (normal cord serum T3U range relative to pooled control reference was 78 to $110 \%$ ). Infants in whom the TSH value was $>45 \mu \mathrm{U} / \mathrm{ml}$ were followed-up as quickly as possible with additional venous T4, TSH, T3U and, in some cases, total serum triiodothyronine (T3) by RIA (Chopra et al., 1972).

If a persistent abnormality of the thyroid function was noted, the infant was investigated further at the

Table 1 Definitions of nomenclature in text

\begin{tabular}{|c|c|c|c|}
\hline \multicolumn{3}{|c|}{ Cord blood screening parameters } & \multirow{2}{*}{$\begin{array}{l}\text { Final clinical and laboratory } \\
\text { diagnoses }\end{array}$} \\
\hline $\begin{array}{l}\text { T4 } \\
\text { (centile) }\end{array}$ & $\begin{array}{l}T S H \\
(\mu U / m l)\end{array}$ & $\begin{array}{l}T 3 U \\
(\%)\end{array}$ & \\
\hline $\begin{array}{l}<12 \text { th } \\
<12 \text { th } \\
<12 \text { th } \\
<12 \text { th }\end{array}$ & $\begin{array}{l}>100 \\
50-100 \\
<6 \\
<30\end{array}$ & $\begin{array}{l}\text { Low, } \mathbf{N}^{*} \\
\text { Low, } \mathbf{N} \\
\text { Low, } \mathbf{N} \\
\text { High }\end{array}$ & $\begin{array}{l}\text { Severe primary hypothyroidism } \\
\text { Other primary hypothyroidism } \\
\text { Secondary hypothyroidism } \\
\text { Hypo-TBG-aemia }\end{array}$ \\
\hline
\end{tabular}

$* \mathbf{N}=$ normal.
Hospital for Sick Children, Toronto; investigations included repeat serum thyroid function studies, a low dose radioiodine uptake, a technetium thyroid scan, and bone age studies (Greulich and Pyle, 1959).

A low dose $(1-2 \mu \mathrm{Ci})^{131}$-I uptake was obtained at 2 and 24 hours. This was followed by a technetium 99M rectilinear scan using a $0.5-2 \mathrm{mCi}$ IV dose according to body surface area.

Table 1 gives the nomenclature used.

\section{Results}

Thyroid indices on cord blood and at the time of follow-up for the 16 hypothyroid infants are shown in Table 2 , including the in-assay location of the cord blood thyroxine value. A summary of the results according to underlying aetiology is shown in Table 3.

The cord blood serum T4 levels in the 16 hypothyroid infants ranged from 2.9 to $8.1 \mu \mathrm{g} / 100 \mathrm{ml}$

Table 3 Aetiological classification for the 16 infants with thyroid abnormalities

\begin{tabular}{lc}
\hline & Total \\
\hline Primary thyroid dysfunction & \\
Severe primary hypothyroidism & 4 \\
Athyrosis & 4 \\
Enzyme defect (goitrous) & 3 \\
Lingual thyroid & \\
Other primary hypothyroidism & 3 \\
Hypoplasia & 1 \\
Iodide induced (transient) & \\
Secondary hypothyroidism & 1 \\
Hypothalamic & \\
\hline
\end{tabular}

Table 2 Thyroid indices on cord blood and at follow-up for the 16 hypothyroid infants screened

\begin{tabular}{|c|c|c|c|c|c|c|c|c|}
\hline \multirow[t]{2}{*}{ Case } & \multicolumn{4}{|l|}{ Cord blood } & \multicolumn{4}{|c|}{ Follow-up } \\
\hline & $\begin{array}{l}T 4 \\
(\mu \mathrm{g} / 100 \mathrm{ml})\end{array}$ & $\begin{array}{l}\text { T4 in-assay } \\
\text { location } \\
\text { (centile) }\end{array}$ & $\begin{array}{l}T S H \\
(\mu U / m l)\end{array}$ & $\begin{array}{l}T 3 U \\
(\%)\end{array}$ & $\begin{array}{l}T 4 \\
(\mu \mathrm{g} / 100 \mathrm{ml})\end{array}$ & $\begin{array}{l}T S H \\
(\mu U / m l)\end{array}$ & $\begin{array}{l}T 3 U \\
(\%)\end{array}$ & $\begin{array}{l}T 3(R I A) \\
(n g / 100 \mathrm{ml})\end{array}$ \\
\hline 1 & $6 \cdot 4$ & $4 \cdot 2$ & 188 & NSQ & $2 \cdot 3$ & 74 & 68 & 123 \\
\hline 2 & $7 \cdot 2$ & $7 \cdot 6$ & $>96$ & 80 & $2 \cdot 6$ & 192 & 77 & NSQ \\
\hline 3 & $2 \cdot 9$ & 0.3 & 300 & 100 & $<1$ & 300 & 86 & 92 \\
\hline 4 & $3 \cdot 8$ & 0.6 & $>96$ & 105 & $1 \cdot 8$ & 300 & 90 & 50 \\
\hline 5 & $6 \cdot 9$ & $3 \cdot 6$ & 192 & 80 & 1.9 & 192 & 80 & NSQ \\
\hline 6 & $3 \cdot 8$ & 0.6 & 128 & 88 & $<1$ & 128 & 81 & NSQ \\
\hline 7 & $3 \cdot 7$ & 0.4 & 180 & 87 & $3 \cdot 1$ & 160 & 81 & 199 \\
\hline 8 & $3 \cdot 7$ & $0 \cdot 3$ & 300 & 90 & $2 \cdot 3$ & 300 & 71 & 105 \\
\hline 9 & $7 \cdot 2$ & $4 \cdot 9$ & 108 & 99 & $5 \cdot 1$ & 45 & 95 & 148 \\
\hline 10 & $4 \cdot 7$ & $0 \cdot 3$ & 300 & 109 & $1 \cdot 5$ & 300 & 84 & 30 \\
\hline 11 & $3 \cdot 8$ & $1 \cdot 4$ & 300 & 101 & $<1$ & 300 & 75 & 75 \\
\hline 12 & $5 \cdot 3$ & $3 \cdot 4$ & 119 & 87 & $4 \cdot 4$ & 47 & NSQ & 56 \\
\hline 13 & $8 \cdot 1$ & $8 \cdot 9$ & 79 & 100 & $8 \cdot 1$ & 66 & 105 & 100 \\
\hline 14 & $7 \cdot 1$ & $11 \cdot 7$ & 49 & 104 & $12 \cdot 4$ & 40 & NSQ & NSQ \\
\hline 15 & $6 \cdot 5$ & $4 \cdot 8$ & 73 & 76 & $2 \cdot 8$ & 126 & 70 & 224 \\
\hline 16 & $6 \cdot 5$ & $4 \cdot 0$ & $<6$ & NSQ & $4 \cdot 1$ & $1 \cdot 4$ & 101 & 93 \\
\hline
\end{tabular}

NSQ $=$ not sufficient quality (for analysis).

Conversion: traditional units to $S I-\mathrm{T} 4: 1 \mu \mathrm{g} / 100 \mathrm{ml} \approx 12.87 \mathrm{nmol} / 1 ; \mathrm{T} 3: 1 \mathrm{ng} / \mathrm{ml} \approx 1.536 \mathrm{nmol} / 1$. 
(37 to $104 \mathrm{nmol} / \mathrm{l}$ ), Table 2 . The mean $\pm \mathrm{SD}$ was $5 \cdot 5 \pm 1 \cdot 7 \mu \mathrm{g} / 100 \mathrm{ml}(71 \pm 22 \mathrm{nmol} / \mathrm{l})$. This was significantly lower by Student's $t$ test $(\mathrm{P}<0.001)$ than the mean T4 of $10.7 \mu \mathrm{g} / 100 \mathrm{ml}(138 \mathrm{nmol} / \mathrm{l})$ for 4911 normal euthyroid infants previously reported (Walfish, 1976). Eight of the 16 hypothyroid infants had T4 levels within 2 SDs of the normal mean (Table 2). When only those infants with severe primary hypothyroidism (Table 1) are studied, the mean T4 is $4.9 \pm 1.6 \mu \mathrm{g} / 100 \mathrm{ml}(63 \pm 21 \mathrm{nmol} / \mathrm{l})$ which is not significantly different from the mean for all the hypothyroid infants. However, those without severe primary hypothyroidism have a mean T4 of $6 \cdot 7 \pm 1.6 \mu \mathrm{g} / 100 \mathrm{ml}(86 \pm 21 \mathrm{nmol} / \mathrm{l})$, significantly higher $(\mathrm{P}<0.05)$ than for other hypothyroid infants. At follow-up the level of T4 had decreased in all except the 2 infants with hypoplasia.

All infants with primary hypothyroidism had cord TSH $>45 \mu \mathrm{U} / \mathrm{ml}$. Those infants with severe primary hypothyroidism had $\mathrm{TSH}>100 \mu \mathrm{U} / \mathrm{ml}$. In all cases (except for the child with secondary hypothyroidism), TSH levels remained $>40 \mu \mathrm{U} / \mathrm{ml}$ at the time of the 3-5 week follow-up, when the normal TSH level is less than $10 \mu \mathrm{U} / \mathrm{ml}$.

Total serum T3 (RIA) was obtained in 11 hypothyroid infants at the time of follow-up and ranged from $30-225 \mathrm{ng} / 100 \mathrm{ml}(0 \cdot 5-3 \cdot 4 \mathrm{nmol} / \mathrm{l})$. T3 (RIA) was subnormal (compared with normal adult values) in only 4 of the affected infants and was not a good indicator of hypothyroidism. 14 hypothyroid infants had T3U performed and, in all except one, T3U was within normal limits. Values tended to be parallel to the T4 values, but no infant had a T3U suggestive of primary thyroxine-binding globulin abnormality.

$149(0.3 \%$ of the total population) infants have been recalled for suspect primary hypothyroidism. When the number of affected infants is subtracted from the total number recalled and expressed as a percentage, $90 \%$ of the recalled infants were proved to be euthyroid at follow-up. 51 infants with T4 in the lowest 12 th centile and T3 uptakes $>120 \%$ were not recalled for suspect hypothyroidism but were followed up, and 8 were shown to have a persistent TBG abnormality. The estimated incidence for our population is therefore $1 / 6500$, which is greater than the incidence previously reported (Dussault et al., 1977 ) in which direct measurements of TBG were used.

As the TSH assay used in this programme was no more sensitive at its lower limits than $6 \mu \mathrm{U} / \mathrm{ml}$, it mainly helped to detect primary hypothyroidism. Case 16 was discovered fortuitously to have secondary hypothyroidism, as he was recalled in the early stages of our programme when all infants with low T4 levels were followed up. More recently, those patients with cord serum T4 values in the lowest 12 th centile with values below the lower limits of detectability on the supplementary TSH test have not been recalled, and this has reduced the percentage recalled for primary hypothyroidism to $0 \cdot 16 \%$ by excluding follow-up of low T4 infants with low TSH (i.e. possible hypo-TBG-aemia or secondary hypothyroidism).

\section{Clinical studies}

Salient data for the 16 infants with thyroid function abnormalities are summarised in Table 4 . The babies ( 9 boys and 7 girls) ranged in gestation from 34 to 42 weeks. Only one (Case 13) had an abnormal birthweight, being low for gestational age. This child had the additional problems of hypospadias, hypoglycaemia, and hypocalcaemia. Follow-up examination was generally between the 14th and 39th day. However, 2 babies in the series were seen laterCase 1 at 80 days, because of a change in her address, and Case 16, who has hypopituitarism, at 308 days, due to reluctance in referral by his doctor. No hypothyroid infant discovered in the screening programme had earlier been suspected to have

Table 4 Clinical data for the 16 infants with thyroid abnormalities

\begin{tabular}{|c|c|c|c|c|c|c|c|c|c|c|c|c|c|c|c|c|}
\hline \multirow[t]{2}{*}{ Data } & \multicolumn{16}{|l|}{ Case } \\
\hline & $I$ & 2 & 3 & 4 & 5 & 6 & 7 & 8 & 9 & 10 & 11 & 12 & 13 & 14 & 15 & 16 \\
\hline $\begin{array}{l}\text { Sex } \\
\text { Gestation (weeks) } \\
\text { Birthweight (g) } \\
\text { Follow-up examination day } \\
\text { Length centile } \\
\text { Height centile } \\
\text { Goitre } \\
\text { Clinical hypothyroidism* } \\
\text { Bone age (weeks gestation) } \\
\text { 4-hour radio uptake }(9-26 \%) \\
\text { Thyroid scan }\end{array}$ & $\begin{array}{l}\text { F } \\
42 \\
4300 \\
80 \\
90 \\
5 \\
- \\
+ \\
38 \\
2 \cdot 2 \\
\text { A. }\end{array}$ & $\begin{array}{l}\text { M } \\
40 \\
3600 \\
23 \\
90 \\
90 \\
- \\
- \\
40 \\
0 \cdot 5 \\
\text { A }\end{array}$ & $\begin{array}{r}\text { F } \\
41 \\
3220 \\
25 \\
10 \\
75 \\
- \\
- \\
38 \\
0\end{array}$ & $\begin{array}{l}\text { F } \\
34 \\
1760 \\
33 \\
3 \\
3 \\
- \\
+ \\
36 \\
2 \cdot 0 \\
\text { A }\end{array}$ & $\begin{array}{l}\text { M } \\
38 \\
3450 \\
24 \\
10 \\
25 \\
+ \\
+ \\
38 \\
40 \\
G\end{array}$ & $\begin{array}{r}\text { F } \\
37 \\
2860 \\
23 \\
5 \\
5 \\
+ \\
+ \\
38 \\
42 \\
G\end{array}$ & $\begin{array}{l}\mathbf{M} \\
40 \\
3210 \\
31 \\
20 \\
50 \\
+ \\
- \\
36 \\
33 \\
G\end{array}$ & $\begin{array}{r}M \\
34 \\
2520 \\
14 \\
3 \\
3 \\
- \\
- \\
36 \\
6 \cdot 6 \\
G\end{array}$ & $\begin{array}{l}M \\
40 \\
3150 \\
39 \\
90 \\
75 \\
- \\
- \\
38 \\
3 \cdot 5 \\
L\end{array}$ & $\begin{array}{r}\mathrm{F} \\
36 \\
2130 \\
27 \\
3 \\
3 \\
- \\
+ \\
38 \\
2 \cdot 0 \\
\mathrm{~L}\end{array}$ & $\begin{array}{r}\text { F } 39 \\
2900 \\
15 \\
10 \\
3 \\
-4 \\
+4 \\
38 \\
4\end{array}$ & $\begin{array}{l}\text { M } \\
34 \\
2030 \\
32 \\
3 \\
3 \\
- \\
- \\
38 \\
7 \cdot 4 \\
\mathbf{H}\end{array}$ & $\begin{array}{r}M \\
40 \\
1600 \\
28 \\
3 \\
3 \\
- \\
- \\
40 \\
8 \cdot 1 \\
\text { ND }\end{array}$ & $\begin{array}{c}\text { F } \\
40 \\
2980 \\
26 \\
10 \\
50 \\
- \\
- \\
40 \\
5 \cdot 2 \\
H\end{array}$ & $\begin{array}{c}M \\
40 \\
3500 \\
30 \\
90 \\
75 \\
- \\
- \\
40 \\
G^{31}\end{array}$ & $\begin{array}{l}M \\
42 \\
3000 \\
308 \\
3 \\
75 \\
- \\
+ \\
38 \\
\text { ND } \\
\text { ND }\end{array}$ \\
\hline
\end{tabular}

* = Criteria of Smith; $A$ = athyrosis; $\mathbf{G}=$ goitre; $\mathrm{L}=$ lingual; $\mathbf{H}=$ hypoplasia; $\mathrm{ND}=$ not done; 
clinical hypothyroidism. At the initial examination all babies were assessed for hypothyroidism using the criteria of Smith et al. (1975). Seven out of 16 had at least one of these criteria; the remaining ones were clinically euthyroid. Three babies had enlarged thyroids, 2 of whom were in the overtly hypothyroid group. The heights and weights of the study group were in the normal range with the exception of 4 premature infants and Case 13. Several babies (Cases 3, 5, 7, 14, and 16) were overweight for their length but only 2 of them were clinically hypothyroid.

Radiological bone age, estimated by the method of Greulich and Pyle (1959), and compared with the age at assessment, was abnormal in 8 of the babies whereas the 24-hour radioiodine uptake was abnormal in all 15.11 babies had a low uptake, while 3 of the 4 babies with enzyme defects, and the infant with iodine-induced goitre, had increased uptake. Technetium scan detected hypoplastic lingual thyroids in 3 (Cases 9, 10, and 11) and suggested athyrosis in 4 others. The diagnoses made are given in Table 3. 11 infants had significant primary hypothyroidism requiring thyroid replacement with L-thyroxine $5 \cdot 0-7 \cdot 5 \mu \mathrm{g} / \mathrm{kg}(64-96 \mathrm{nmol} / \mathrm{kg})$ a day. Treatment was started in this group between 15 and 80 days, with a mean starting day of 32 , and more recently of 22 days. Case 15, with iodide-induced hypothyroidism, was initially treated with Lthyroxine but his treatment was stopped at age 2 months when the cause was established and he remained euthyroid at subsequent follow-ups. The 3 infants with hypoplasia had subclinical hypothyroidism at reassessment; and 2 were treated with thyroxine replacement but one of these, Case 12, died from sepsis and at necropsy his thyroid gland was shown to be hypoplastic. The family of the one remaining baby in this group, Case 14, elected not to allow treatment, and at age 12 months he was physically and developmentally normal but he still had a raised TSH with normal T4 and T3 levels. Case 16 with hypopituitarism, has hypogonadotropic hypogonadism, and hypothyroidism associated with congenital microcephaly, and moderately severe developmental delay. Thyroid replacement in this child improved his height velocity.

\section{Discussion}

This cord blood programme using initial T4 screening with supplemental TSH determination gave a yield of thyroid abnormalities of $1 / 3000$ births with a 1/5000 incidence of severe primary hypothyroidism. This correlates well with the findings of other screening programmes using either cord blood or dried blood spots (Fisher et al., 1976). This is a much greater incidence than that for phenylketonuria $(1 / 16000)$ for which screening programmes already exist, and much greater than $1 / 20000$ estimated from retrospective examination of hospital admissions for cretinism in Toronto (unpublished data). The discrepancy may be caused by early detection of cases that would not have presented with cretinism. However, those cases without athyrosis (i.e. enzyme defect, lingual thyroid, etc.), although biochemically hypothyroid, may in fact not have developed clinical hypothyroidism until later. The particular significance of the 3 cases of hypoplasia is not clear. Such cases may represent either subclinical hypothyroidism or a form of pituitary resistance syndrome where there is a raised serum TSH in the presence of a normal to raised serum T4 concentration (Gershengorn and Weintraub, 1975).

Our programme requires supplementary TSH estimations on the lower 8-12th centile of the T4 'run'. This high incidence of supplemental TSH determination using cord blood serum is necessary because T4 levels may be low in premature infants, twins, and in other euthyroid infants (Walfish, 1976; Ginsberg et al., 1978). The technical and clinical problems that could arise from using an absolute value of T4 for determining which samples have supplemental TSH testing within a screening programme has previously been discussed (Walfish, 1976). As the cord serum T4 was within the 95th centile of the normal population for most of the affected hypothyroid infants, we feel it is necessary to take a relatively large number of infant samples for supplemental TSH estimations to avoid the possibility of missing a hypothyroid infant. Similarly, a hypothyroid infant with cord serum T4 values above the lower $2 \cdot 5$ th centile of the normal general population has been reported (Klein et al., 1976). Because of its relative nonspecificity and the high recall burden imposed by screening for $\mathrm{T} 4$ alone, it is not recommended as the only screening technique (Walfish, 1976; Scriver et al., 1977; Dussault, et al. 1978).

Several high false-positive TSH values were seen secondary to extreme parturition stress (Walfish, 1976; Delange et al., 1977). No false-negative results have so far been seen as all infants with primary hypothyroidism had TSH values $>45$ $\mu \mathrm{U} / \mathrm{ml}$, and those with very significant primary hypothyroidism had values $>100 \mu \mathrm{U} / \mathrm{ml}$. As stated earlier, TSH is the single most specific test for detecting infants with primary hypothyroidism. Because of the cost of reagents and the need for technical expertise (and the inability to detect secondary hypothyroidism or TBG abnormalities), we have not advocated a TSH test as the only screening method. However, if one wanted to rely on a single 
test to detect primary hypothyroidism, TSH screening would seem to be the most appropriate. So far our programme, using an initial T4 with a supplementary TSH and T3U test on cord blood serum, has decreased the number of patients needed to be followed up for primary neonatal hypothyroidism to an acceptable $0 \cdot 16 \%$ of the total population. If a cord blood sample is not received, then a dried blood heel prick spot is obtained at between 3 and 5 days and initial T4 and supplementary TSH tests performed. To our knowledge, no infant with primary hypothyroidism has failed to be detected (i.e. no false-negative results).

The clinical and laboratory data recorded here are somewhat at variance with those in current texts. Rather than showing a female preponderance (Carr et al., 1961; Andersen, 1969), the sex ratio is equal, but the small number of subjects may be the reason for this. Fewer than half of the cases showed any criterion of hypothyroidism using the parameters of Smith (Smith et al., 1975). This finding is in direct contrast to that of Guyda et al. (1977), but it is in agreement with the data of others; Klein et al. (1976) found little clinical evidence of hypothyroidism among their detected infants. In contrast to other reports (Smith et al., 1957, 1975), delayed radiological bone age, as an index of skeletal maturation, did not correlate well with hypothyroidism in our series.

While awaiting the results of the hormone assay, a low dose 24-hour radioiodine thyroid uptake was performed and, if this was abnormal, replacement therapy could be begun. Technetium scanning allowed the defect in the thyroid to be estimated so that appropriate genetic counselling could be given to the parents. A low dose ${ }^{131}$-I uptake procedure was routinely performed but the technetium $99 \mathrm{M}$ scan could be used instead for the anatomical localisation of the thyroid gland abnormality with less radiation exposure. Nevertheless, information on goitrous lesions and their underlying biosynthetic defects can be obtained from radioiodine studies ( ${ }^{123}$-I preferably if available) at negligible radiation risk if the appropriate low doses are used.

The distribution of diagnoses in this small number of cases differs from that in previous reports in which it is suggested that most cretins have athyrosis (Wilkins, 1960; Carr et al., 1961). In our group only $30 \%$ were athyrotic, $30 \%$ had enzyme defects, and $20 \%$ lingual glands. This distribution is similar to that found by others (Andersen, 1966) from an analysis of congenital hypothyroidism based on radioiodine thyroid uptake.

Cord blood serum is easy to obtained, it can be handled easily, and it requires less cumbersome radioimmunoassay procedures for T4 and TSH than the dried blood spot. Excess serum is also readily available for repeat analyses and for T3U tests for determining abnormal thyroid hormone protein binding. The main difficulty with such a method is that the sample has to be sent to a central laboratory and then isolated from other inborn error screening tests. Dried blood placed on filter paper is an alternative method and has the advantage that it can be transported over wide areas (Fisher et al., 1976; Scriver, 1977; Dussault et al., 1978). Such a technique may be combined with screening for phenylketonuria and with other inborn error screening programmes that can be assayed from neonatal dried blood filter paper discs (Scriver et al., 1977). However, assays performed from dried blood filter paper discs require proper collection and saturation of both surfaces of the filter paper (Walfish, 1975), and there is the risk of blood TSH instability and a significant reduction in measurable TSH activity within several weeks at high ambient temperatures (Naruse, 1978; P. G. Walfish, 1979, in preparation) such as may occur if they are sent by post. The estimated cost for the cord blood screening programmes as described, using initial cord blood serum T4 determinations with supplementary TSH and T3U assays is $\$ 1.50$ per infant excluding overhead and capital equipment expenditures, but other dried blood programmes have reported similar or lower costs (Fisher et al., 1976).

Regardless of whether cord blood serum or neonatal dried blood is used, screening programmes for neonatal hypothyroidism will find it difficult to detect infants with secondary hypothyroidism (low T4 with low TSH) who reportedly represent between 6 and $10 \%$ of the total neonatal hypothyroid population (Fisher et al., 1976; Dussault et al., 1978). However, the low incidence of secondary hypothyroidism, its difficulty of detection, and the overlap with normal infants having low TSH values will require an unusually high burden of recall of over $1 \%$ of the population surveyed (Dussault et al., 1978) in order to detect such cases; this is a known limitation of any screening programme regardless of method, owing to the poor discrimination between infants with low TSH secondary hypothyroidism, those with low TSH of congenital hypo-TBG, and normal infants. Our programme has therefore recently been altered to screen only for primary neonatal hypothyroidism and this has further reduced the number recalled to $0 \cdot 16 \%$.

Despite these limitations, the high incidence of thyroid abnormalities detected by cord blood screening has shown that this approach may be as effective as neonatal dried blood screening methods in detecting neonatal hypothyroidism if the appropriate recall criteria and transport conditions are used. This study shows that cord blood serum screening was successful 
in detecting neonatal hypothyroidism within densely concentrated population areas with high birth rates, provided that a central assay laboratory is available to optimise quality control and to reduce administrative costs. Nevertheless, owing to the practical considerations, and in agreement with previous reports (Fisher et al., 1976; Scriver et al., 1977), we recommend the neonatal dried blood collection method as the screening test of choice when surveying large populations over extensive geographical regions.

Although supported by retrospective studies (Raiti and Newns, 1971; Klein et al., 1972), the value of prompt detection and early thyroxine replacement remains to be assessed prospectively, in our cases of primary hypothyroidism. It is too soon to assess accurately the intellectual development for these infants, but at present all primary cases appear to be growing at a normal velocity and have normal motor milestones, suggesting that early detection and therapy have been of significant value.

We appreciate the technical assistance of Mrs E. Gera, Mrs M. Grant, Mrs A. Bansil, Dr R. Talosig, Mrs M. Weiner; the nursing assistance of Mrs C. Schonberg, the secretarial assistance of Miss S. Windatt; the US National Institutes of Health, (National Institute of Arthritis, Digestive and Metabolic Diseases) Pituitary Agency, the WHO and Division of Biological Standards, Holly Hill, UK for TSH and their supplies, and the volunteer assistance for the refrigerated cord blood pick-up and transport of the Toronto Chapter of the Canadian Red Cross; the obstetric and paediatric staff of all participating hospitals; and the assistance of Dr J. Bailey of the Hospital for Sick Children, Endocrine Service, Toronto.

This work was sponsored by grants from Health and Welfare Canada, Ontario Ministry of Health PR 527, Mount Sinai Hospital Institute and Department of Medicine Research Fund, the Nathan and Toby Starr Endowment Fund for Research in Mental Retardation, and the Hospital for Sick Children Foundation, Toronto.

Presented in part at the Sixteenth Annual Meeting of the European Society for Pediatric Endocrinology, 14-17 September, 1977, Cambridge England. (Pediatric Research, 1978, 12, 154A).

\section{References}

Andersen, H. J. (1966). Congenital hypothyroidism. Sandoz Journal of Medicine and Science, 7, 210-220.

Andersen, H. J. (1969). Nongoitrous Hypothyroidism in Endocrine and Genetic Diseases of Childhood, pp. 216-234. Edited by L. I. Gardner. Saunders: Philadelphia.
Carr, E. A., Beierwaltes, W. H., Neel, J. V., Davidson, R., Lowrey, G. H., Dodson, V. N., and Tanton, J. H. (1961). The various types of thyroid malfunction in cretinism and their relative frequency. Pediatrics, 28, 1-16.

Chopra, I. J. (1972). A radioimmunoassay for measurement of thyroxine in unextracted serum. Journal of Clinical Endocrinology and Metabolism, 34, 938-947.

Chopra, I. J., Ho, R. S., and Lam, R. (1972). An improved radioimmunoassay of triiodothyronine in serum: its application to clinical and physiological studies. Journal of Laboratory and Clinical Medicine, 80, 729-739.

Delange, F., Camus, M., Winkler, M., Dodion, J., and Ermans, A-M. (1977). Serum thyrotropin determination on day 5 of life as a screening procedure for congenital hypothyroidism. Archives of Disease in Childhood, 52 89-96.

Dussault, J. H., Letarte, J., Guyda, H., and Laberge, C. (1976). Thyroid function in neonatal hypothyroidism. Journal of Pediatrics, 89, 541-544.

Dussault, J. H., Letarte, J., Guyda, H., and Laberge, C. (1977). Serum thyroid hormone and TSH concentrations in newborn infants with congenital absence of thyroxinebinding globulin. Journal of Pediatrics, 90, 264-265.

Dussault, J. H., Morrissette, J., Letarte, J., Guyda, H., and Laberge, C. (1978). Modification of a screening program for neonatal hypothyroidism. Journal of Pediatrics, 92, 274-277.

Fisher, D. A., Burrow, G. N., Dussault, J. H., Hollingsworth, D. R., Larsen, P. R., Man, E. B., and Walfish, P. G. (1976). Recommendations for screening programs for congenital hypothyroidism. Journal of Pediatrics, 89, 692-694.

Foley, T. P., Jr, Klein, A. H., and Agustin, A. V. (1977). Adaptation of TSH filter paper method for regionalised screening for congenital hypothyroidism. Journal of Laboratory and Clinical Medicine, 90, 11-17.

Gershengorn, M. C., and Weintraub, B. D. (1975). Thyrotropin-induced hyperthyroidism caused by selective pituitary resistance to thyroid hormone. Journal of Clinical Investigation, 56, 633-642.

Ginsberg, J., Walfish, P. G., and Chopra, I. J. (1978). Cord blood reverse T3 in normal, premature, euthyroid low T4, and hypothyroid newborns. Journal of Endocrinological Investigation, 1, 73-77.

Greulich, W. W., and Pyle, S. I. (1959). Radiographic Atlas of Skeletal Development of Hand and Wrist. Stanford: California.

Guyda, H., Letarte, J., Dussault, J., and Laberge, C. (1977). Clinical features of congenitally hypothyroid babies diagnosed by the Quebec screening network (abstract). Annals of the Royal College of Physicians and Surgeons of Canada, 10, 48.

Illig, R., and Rodriguez de Vera Roda, C. (1976). Radioimmunologischer Nachweiss von TSH in getrockneten Blutstrofen; mögliche Screeningmethode zur Entdeckung der Hypothyreose bei Neugeborenen. Schweizerische medizinische Wochenschrift, 106, 1676-1681.

Irie, M., Enomoto, K., and Naruse, H. (1975). Measurements of thyroid-stimulating hormone in dried blood spot. Lancet, 2, 1233-1234.

Klein, A. H., Meltzer, S., and Kenny, F. M. (1972). Improved prognosis in congenital hypothyroidism treated before age three months. Journal of Pediatrics, 81, 912-915.

Klein, A. H., Agustin, A. V., and Foley, T. P., Jr (1974). Successful laboratory screening for congenital hypothyroidism. Lancet, 2, 77-79.

Klein, A. H., Foley, T. P., Jr, Larsen, P. R., Agustin, A. V., and Hopwood, N. J. (1976). Neonatal thyroid function in congenital hypothyroidism. Journal of Pediatrics, 89, 545-549. 
Larsen, P. R., Merker, A., and Parlow, A. F. (1976). Immunoassay of human TSH using dried blood samples. Journal of Clinical Endocrinology and Metabolism, 42, 987-990.

Miyai, K., Nishi, K., Kawashima, M., Oura, T., and Tsuruhara, T. (1976). An improved assay of thyrotropin in dried blood samples on filter paper as a screening test for neonatal hypothyroidism. Clinica chimica acta, 73, 241-249.

Naruse, H. (1978). Organisation of mass screening in Japan, and TSH screening in the Toyko area. In Newborn Screening for Hypothyroidism. Edited by D. A. Fisher and R. Koch. Bulletin 78-5293. Department of Health, Education, and Welfare: Maryland.

Patel, Y. C., Burger, H. G., and Hudson, B. (1971). Radioimmunoassay of serum thyrotropin: sensitivity and specificity. Journal of Clinical Endocrinology and Metabolism, 33, 768-774.

Raiti, S., and Newns, G. H. (1971). Cretinism: early diagnosis and its relation to mental prognosis. Archives of Disease in Childhood, 46, 692-694.

Scriver, C. R., Feingold, M., Mamunes, P., and Nadler, H. L. (1977). Screening for congenital metabolic disorders in the newborn infant. Congenital deficiency of thyroid hormone and hyperphenylalaninemia. Pediatrics, 60, 391-395.

Smith, D. W., Blizzard, R. M., and Wilkins, L. (1957). The mental prognosis in hypothyroidism of infancy and childhood. Pediatrics, 19, 1011-1022.

Smith, D. W., Klein, A. H., Henderson, J. R., and Myrianthopoulos, N. C. (1975). Congenital hypothyroidism: signs and symptoms in a newborn period. Journal of Pediatrics, 87, 958-962.

Walfish, P. G. (1975). Screening for neonatal hypothyroidism using a dried capillary blood method. Observations on methodological factors, selection criteria, and preliminary results. In Perinatal Thyroid Physiology and Disease, pp. 239-247. Edited by D. A. Fisher and G. N. Burrow. Raven Press: New York.

Walfish, P. G. (1976). Evaluation of three thyroid function screening tests for detecting neonatal hypothyroidism. Lancet, 1, 1208-1211.

Walfish, P. G., O'Donnell, J., Gelbard, A., and Pollard, A. (1973). Clinical application of a radioimmunoassay for thyroxine in unextracted serum. Comparison with a competitive protein binding method (abstract). Clinical Research, 21, 1031A.

Wilkins, L. (1960). Hypothyroidism in children. In Clinical Endocrinology, volume 1, pp. 112-122. Edited by E. B. Astwood. Grune and Stratton: New York.

Correspondence to Dr Paul G. Walfish, Mount Sinai Hospital, Suite 640, 600 University Avenue, Toronto, Ontario M5G 1X5, Canada.

Received 22August 1978 